Article

\title{
Does the Stock Market Value Inclusion in a Sustainability Index? Evidence from Borsa Istanbul
}

\author{
Mustafa K. Yilmaz ${ }^{1}\left(\mathbb{D}\right.$, Mine Aksoy ${ }^{2, *}$ a and Ekrem Tatoglu 1,3 \\ 1 School of Business, Ibn Haldun University, Ulubatli Hasan Cad., No: 2 Basaksehir, 34494 Istanbul, Turkey; \\ mustafa.yilmaz@ihu.edu.tr (M.K.Y.); etatoglu@sharjah.ac.ae or ekrem.tatoglu@ihu.edu.tr (E.T.) \\ 2 Faculty of Economics and Administrative Sciences, Yalova University, Yalova Üniversitesi Merkez Yerleşkesi, \\ Çınarcık Yolu Üzeri, 77200 Yalova, Turkey \\ 3 College of Business Administration, University of Sharjah, Sharjah P.O. Box 27272, UAE \\ * Correspondence: maksoy@yalova.edu.tr
}

Received: 7 December 2019; Accepted: 3 January 2020; Published: 8 January 2020

check for updates

\begin{abstract}
This study examines the relationships between corporate sustainability (CS) performance of the companies (proxied by inclusion in sustainability index) listed in Borsa Istanbul (BIST, Istanbul, Turkey) and market-specific company performance measures over the period of 2014-2017. The results show that there is no strong evidence of the effect of inclusion in or exclusion from the BIST Sustainability Index (BIST SI) on stock returns and systematic risk (betas) of companies. However, the results reveal that inclusion in the BIST SI reduces the total risk of the companies and protects them from stock declines in case of a severe crisis by improving their resilience compared to other companies not included in the BIST SI. Although no significant link is found concerning the impact of the companies' inclusion on the level of foreign ownership, a positive association is noted between BIST SI inclusion and the level of institutional ownership.
\end{abstract}

Keywords: corporate sustainability performance; sustainability index; stakeholder theory; market reaction; Turkey

\section{Introduction}

The ethical and social aspects of business increasingly serve a crucial role in the sustainable growth of companies, especially concerning the changing expectations of stakeholders. Thus, companies have to communicate more information to third parties about their environmental, social, and governance (ESG) performance to show their commitment to ESG issues as a responsible entity [1]. They have to manage the ESG impacts properly to stay sustainable in an increasingly competitive business environment.

Overwhelmingly, in recent years, companies increasingly have been declaring themselves sustainable and releasing sustainability reports along with their annual reports. One key reason for this is portfolio managers' increasing interest in more socially responsible investments (SRI). As stated by the Global Sustainable Investment Review [2], over the last decade, the amount of assets under management has increased rapidly, reaching USD 30.7 trillion globally in 2017, accounting for 40 percent of the total. The primary motivation behind this growth is that mutual and pension funds view sustainable or impact-based investing as critical to long-term investment and risk mitigation.

In parallel to this approach, capital markets have also begun to serve a vital role in promoting sustainability in their institutions by encouraging or requiring ESG disclosure, issuing formal guidance, offering ESG training, running ESG events, and collaborating with external organizations. In fact, the very first step was taken during the Rio+20 summit held in 2012, where five stock exchanges-namely Nasdaq, Borsa Istanbul, BOVESPA, Johannesburg Stock Exchange, and Egyptian Exchange-signed an agreement pioneering the Sustainable Stock Exchanges Initiative. Since then, the number of stock 
exchanges taking part in this initiative has grown rapidly, reaching 78 in 2018, representing over 75 percent of listed equity markets throughout the world.

While trying to increase transparency, stock exchanges have introduced several products to encourage listed companies to pursue sustainability targets. Many stock exchanges prefer to launch sustainability indices and use this proxy as a way to encourage companies to take further actions to improve their ESG performance and help to reach the United Nations' sustainability development goals declared in 2015. On the other side, several rating agencies evaluate CSP and publish corporate social responsibility (CSR) indices or SRI indices to consider financial as well as the non-financial ESG factors. These indices provide investors or fund managers with information about a company's CSP and help build CSP portfolios at a low cost [3].

This growing interest in sustainability has also led to an increase in the volume of academic studies investigating the link between ESG practices of companies and their financial and market performance. One of the topics that has attracted the attention of academics is the comparison of the market performance achieved by sustainable and conventional companies [4]. In this context, several prior studies examined the effects of inclusion in CSR, SRI, or other sustainability indices on market performance [3,5-13].

Borsa Istanbul (BIST) in Turkey is one of the stock exchanges that launched its sustainability index in 2014 after making tremendous efforts and closely collaborating with all stakeholders. Since then, companies that meet the requirements have been included every year in the BIST Sustainability Index (BIST SI), helping them to become more visible in the eyes of investors.

This study examines the relationship between corporate sustainability (CS) performance and market-specific performance measures of Turkish companies listed in BIST from 2014 to 2017. On this basis, we employ event study methodology to analyze the significance of abnormal returns for companies after the announcement of their inclusion in the BIST SI. The study offers two main contributions to the extant literature. First, it is the first study conducted in a key emerging country market, Turkey, covering the longest time period (2014-2017) in analyzing the relationships between CS performance of the companies listed in BIST (proxied by inclusion in sustainability index) and market-specific company performance measures. As there is an apparent dearth of empirical studies on CS and market-specific company performance links within the context of emerging markets, this study provides a notable contribution to sustainability literature in emerging markets in terms of promoting capital market development and responsible business practices and the impacts that companies and investors can expect [14]. As evident from literature, most prior studies analyzed the markets in North America and Europe, where attention in sustainability has a long history among investors. Secondly, unlike previous studies that rely largely on the use of either single or few performance measures, this study investigates the underlying performance links through various dimensions including the stock return, total risk, gaining access to capital and resilience to crises, which provides an enriched understanding of the phenomenon under investigation.

The rest of the study is structured as follows. The next section provides background literature and develops the study's hypotheses. Section 3 presents the methodology, followed by empirical results. Discussion and conclusion are in the final section.

\section{Theoretical Background and Hypotheses}

Whether it does pay to be sustainable is a question that has not yet been solved by the literature despite the increasing number of studies demonstrating the effect of sustainability performance on the market and corporate financial performance alongside total risks in recent years. One side of this debate is closely related to the principles put forward by the stakeholder theory $[15,16]$. According to this theory, incorporating (avoiding) multiple stakeholders' interests when formulating corporate strategic management policies could improve (damage) the levels of corporate financial and market performance. Friede et al. [17] supported this view in their review of more than 2000 empirical studies by noting that there is a nonnegative ESG-financial performance relationship in nearly $90 \%$ of the 
studies. In the case of corporate sustainability, stakeholders expect companies to undertake additional investments in social areas and ask them to be accountable for CSR issues. However, drawing on agency theory, another side of the debate views CSR as a means for managers to further their career agendas at the expense of shareholders. This theory suggests that resources devoted to CSR could be more wisely spent on increasing firm efficiency. Viewed from this perspective, shareholder gains (losses) may be compensated by losses (gains) to other company stakeholders, leading to a net social loss (gain). This is especially true for firms having lower corporate values since they have limited capacity to effectively reduce their costs regarding stakeholders [18].

At this point, it is also important to note that examining stock price alone is not a proper way to evaluate net social benefits, and by implication, not the most desirable method to test CS performance. For instance, indicating that affirmative action awards result in higher stock prices does not prove that there is no redistribution from other stakeholders. Therefore, we suggest that a better methodological approach is to investigate the net or social impacts of decisions viewed as representing CSR. Doing so involves simultaneously assessing effects on company performance and benefits or losses experienced by other stakeholder groups, such as foreign investors and institutional investors [19].

Another critical theory is related to the reputation effect, which claims that CS performance may have an external impact on corporate reputation, and a firm's communication about its level of CS performance may help build a positive image with its stakeholders. Although corporate reputation has been the subject of scholarly research by using different perspectives, the resource-based view has contributed most to developing the theory of corporate reputation since the 1990s. As a resource, it enables companies to achieve sustainable competitive advantage. From this perspective, the strategic implementation of sustainability within companies is considered as an intangible asset that creates value, and that relates directly to an enhanced reputation and image, higher stakeholder satisfaction, stronger brand, more significant premium, and long-term wealth [20].

However, the potential value of being included in the sustainability index (SI) hinges on how a reputation for sustainability affects the value of the firm and its resistance against a crisis. Since a commitment to ESG activities acts as a sign to stakeholders of the quality of their claims, we expect stakeholders to view companies with an excellent reputation for CS performance more favorably because of this commitment. The topic is so essential that the number of studies has dramatically increased in the last decade, but their findings hitherto yielded mixed results.

Most of the earlier studies concentrate on the relationship between CS performance and stock returns. Dasgupta et al. [21] analyzed how environmental news altered the asset returns of tradable companies in Argentina, Chile, Mexico, and the Philippines from 1990 to 1994, concluding that markets react positively to the announcement of rewards and explicit acknowledgment by the government of superior environmental performance, and negatively to citizens' complaints directed at specific companies.

Curran and Moran [7] investigated the effect on price of inclusion in and deletion from the FTSE4Good Index and found that although there is a trend toward positive and negative announcements having the expected impact on daily returns, these movements are not significant and do not suggest that a company's inclusion in the index produces any substantial financial gain. Similarly, Consolandi et al. [6] examined whether the market reacts to the inclusion (deletion) of companies in the DJ Stoxx SI, and they found that in both cases, evaluation of the CS performance is a major criterion for asset allocation. Junior [22] analyzed whether CSR has an influence on company value for a sample of non-financial Brazilian companies included in the BOVESPA SI compared to other publicly listed companies not included in the index from 2005 to 2007, and found that policies that focus on CSR add value to the company.

Ortas and Moneva [12] studied market reaction to the announcement of variations in the DJSI Stoxx composition and the release to the market of the new sustainable equity index, using an event study based on a multivariate regression model throughout 2003-2007. They found that the companies' inclusions or exclusions are not associated significantly with their stock prices. Likewise, Cheung [5] 
investigated the impact of index inclusions/exclusions on sustainable companies, based on a sample of US stocks added to or deleted from the DJ Sustainability World Index for 2002-2008 in terms of liquidity, risk, and stock return. Using an event study, he found that while announcement as such has no significant effect on stock return and risk, on the day of change, inclusion has a positive and exclusion has a negative effect on stock returns temporarily.

Lourenço et al. [9] searched for empirical evidence on how CS performance, as proxied by the membership of the DJ SI, was reflected in the market value of equity; they found that CS performance has significant explanatory power for the market value, and investors penalize large firms with low CS performance. From another angle, Oberndorfer et al. [11], using a short-term event study based on the Fama and French's [23] three-factor asset pricing model, analyzed the impact on the stock performance of the inclusion of German firms in the DJ Stoxx SI and the DJ Sustainability World Index. The authors found that inclusion in the DJ Sustainability World Index has a negative impact on stock performance, and there are no significant average cumulative abnormal returns for inclusion in the DJ Stoxx SI.

Using the Morningstar SRI Index from 2003 to 2010, Nakai et al. [10] investigated how investors evaluate membership of an SI; they found that while inclusion in the SI positively affects share price, exclusion from the SI does not have a significant effect. They detected negative abnormal returns in previous years and positive abnormal returns in later years, showing that there is a positive change in investors' perceptions about firms' CSR throughout the years. Cheung and Roca [24] studied the effect of the DJ Sustainability World index on stock prices in the Asia Pacific stock markets from 2002 to 2010, concluding that when a company is either included in or excluded from the DJ Sustainability World Index, it leads to a decline in stock price. The authors suggest that an adverse price reaction to inclusion in the DJ Sustainability World Index reflects the pessimistic view of sustainability in the Asia Pacific region.

Cunha and Samanez [25] studied the Corporate Sustainability Index of the Brazilian Mercantile and Futures Stock Exchange (BM\&F BOVESPA), analyzing the performance of sustainable investments on the stock market over the period 2005-2010 using return, liquidity, and risk indicators, as well as Sharpe, Treynor, Sortino, and Omega measures, and they found that sustainable investments have increased liquidity and low diversifiable risk. Sudha [26] compared the performance of the SI of India using the daily index data and analyzed the conditional volatility through GARCH models; the author found that daily compounded returns to the ESG India Index are not statistically different from those of the Nifty or the CNX 500. However, annualized returns of the ESG India Index were superior to the returns in other indices, and the ESG India Index was less volatile compared to the Nifty during the period.

Van Stekelenburg et al. [27] examined the link between financial performance and CS performance by analyzing a sample of European stocks included to or deleted from the DJ Sustainability Europe Index over the period 2009-2013. They found that adding to the index temporarily increases the stock price for one trading day after the announcement, and removal from the index temporarily decreases the stock price for between five and ten trading days after the effective change date. Like Cheung [5] and Van Stekelenburg et al. [28], a study by Robinson et al. [28] demonstrated similar stock market reaction when companies are included in the DJ Sustainability World index. They analyzed the stock prices of 48 North American companies added to and 43 North American companies removed from the DJ Sustainability World Index between 2003 and 2007 and indicated a statistically significant increase in abnormal returns for 60 trading days after a company is added to the DJ Sustainability World Index. However, their results show a statistically insignificant change in abnormal returns after a company is removed from the DJ Sustainability World index.

Joshi et al. [29] explored investors' response to firms' sustainability efforts by referring to inclusion in or exclusion from the DJ Sustainability Index from 2002 to 2011; they found an adverse reaction to both DJSI inclusion/exclusion, indicating that the market evaluates the benefits of sustainability efforts only in the context of costs that such efforts impose on the company's performance. Inclusion is perceived negatively as it signals that sustainability efforts are costly, without corresponding financial 
benefits. Exclusion shows a failure to maintain the focus of the chosen strategy. Hayward [30] analyzed the impact on price over the period 2005-2016 of the announcement when a firm is added to or removed from the DJ North America Sustainability Index (DJSI NA). She noted that while deletion from the DJSI NA has a negative and statistically significant temporary effect on the price for seven trading days following the change date, addition to the index has a positive and significant temporary effect on the stock price for two trading days following the announcement date.

Studies drawing attention to the relationship between CSR and corporate reputation are also worth mentioning. Drawing on a meta-analysis of 52 studies, Orlitzky et al. [31] found that social responsibility and, to a lesser extent, environmental responsibility are likely to pay off, although the CS performance and corporate financial performance also moderate the positive association. They also pointed out that CS performance reputation indices are more highly correlated with corporate financial performance than are other measures of CS performance. Schnietz and Epstein [32] examined the existence of financial value in reputation for CSR during a crisis by analyzing the effects of the failure of World Trade Organization summit in Seattle on the market value of US firms without a reputation for CSR versus that of US firms with a reputation for CSR. They noted that a reputation for CSR protected firms from stock declines related to this crisis, even when controlling for possible trade and industry effects. Karpoff et al. [33] linked share price to reputational capital. They investigated the penalties imposed on 585 companies targeted by enforcement actions of Securities Exchange Commission for financial misrepresentation from 1978-2002, noting that the reputational penalty is over 7.5 times the sum of penalties imposed through the regulatory system, and that reputation loss is positively associated with measures of a company's reliance on implicit contracts.

Hawn et al. [34] examined additions to and deletions from the DJ SI and found that while companies with lower performance benefit more from gaining status and pay higher penalties for losing status, companies with higher market legitimacy benefit less from increased social legitimacy and suffer less from decreased social legitimacy.

Studies held for the Turkish market mostly concentrate on a single dimension of market performance. Çıtak et al. [35] investigated investors' reaction to the announcement of companies included in the BIST SI by comparing the stock returns of 50 BIST companies which are constituents of that index with those of BIST 50 companies that are not included in the index between November 2015 and October 2016. They found no significant difference between the returns of these two groups, except for the interval of 0 to +4 days until +10 days, where there was significant cumulative abnormal return (CAR) for those firms included in the BIST SI.

Table 1 summarizes some of the previous academic studies on the market performance impact of sustainability indices. The following subsections provide a discussion on the logic of the study's hypotheses investigating the links between CS performance and market-specific company performance measures, including the stock return, total risk, gaining access to capital, and resilience to crises. 
Table 1. Summary of previous studies on the market performance impact of sustainability indices.

\begin{tabular}{|c|c|c|c|c|}
\hline Authors & Methodology & Dependent Variable & Independent Variable (s) & Results \\
\hline $\begin{array}{c}\text { Dasgupta et al., (1998) } \\
{[21]}\end{array}$ & Event study & Stock returns & $\begin{array}{l}\text { Environmental news in Argentina, } \\
\text { Mexico, Chile, and the Philippines } \\
\text { (1990-1994) }\end{array}$ & $\begin{array}{l}\text { Markets react positively to the announcement of } \\
\text { rewards for environmental performance and } \\
\text { negatively to citizens' complaints about specific firms }\end{array}$ \\
\hline $\begin{array}{l}\text { Schnietz and Epstein } \\
\text { (2005) [32] }\end{array}$ & Event study & Stock returns & CSR performance & $\begin{array}{l}\text { A positive reputation for CSR protects firms from } \\
\text { stock declines compared to others. }\end{array}$ \\
\hline $\begin{array}{l}\text { Curran and Moran } \\
\text { (2007) [7] }\end{array}$ & Event study & Stock returns & $\begin{array}{l}\text { Impact of inclusion in and deletion from } \\
\text { the FTSE4Good Index }\end{array}$ & $\begin{array}{l}\text { Although positive and negative announcements have } \\
\text { the expected effects on returns, the movements are not } \\
\text { significant and do not suggest that a firm's presence } \\
\text { on the index brings it any significant return. }\end{array}$ \\
\hline Junior (2009) [22] & & Firm value & $\begin{array}{l}\text { CSR performance of non-financial firms } \\
\text { included in BOVESPA SI (2005-2007) }\end{array}$ & $\begin{array}{l}\text { Policies that focus on corporate sustainability add } \\
\text { value to the firm. }\end{array}$ \\
\hline $\begin{array}{l}\text { Consolandi et al., (2009) } \\
\text { [6] }\end{array}$ & Event study & Asset allocation & $\begin{array}{l}\text { Inclusion (deletion) of firms in the DJ } \\
\text { Stoxx SI (2001-2006) }\end{array}$ & $\begin{array}{l}\text { Evaluation of the CSR performance is a significant } \\
\text { criterion for asset allocation. }\end{array}$ \\
\hline Cheung (2011) [5] & Event study & $\begin{array}{l}\text { Stock return, risk, and } \\
\text { liquidity }\end{array}$ & $\begin{array}{l}\text { Inclusion in or exclusion from the DJ } \\
\text { Sustainability World Index (2002-2008) }\end{array}$ & $\begin{array}{l}\text { An announcement has no significant impact on stock } \\
\text { return and risk. On the day of change, inclusion has a } \\
\text { positive, and exclusion a negative, impact on returns. } \\
\text { An announcement has a negative impact on liquidity, } \\
\text { but liquidity goes back significantly near the day of } \\
\text { the change. }\end{array}$ \\
\hline $\begin{array}{l}\text { Ortas and Moneva (2011) } \\
\text { [12] }\end{array}$ & $\begin{array}{l}\text { Event study (multivariate } \\
\text { regression model) }\end{array}$ & Stock returns & $\begin{array}{l}\text { Inclusion in and exclusion from the DJSI } \\
\text { Stoxx with good and bad levels of CSP } \\
\text { (2003-2007) }\end{array}$ & $\begin{array}{l}\text { Firms' inclusion/exclusion is not incorporated } \\
\text { significantly into the prices. }\end{array}$ \\
\hline $\begin{array}{l}\text { Robinson et al., (2011) } \\
{[28]}\end{array}$ & Event study & Stock returns & $\begin{array}{l}\text { Inclusion in and exclusion from the DJ } \\
\text { Sustainability World Index for North } \\
\text { American firms (2003-2007) }\end{array}$ & $\begin{array}{l}\text { There is a statistically significant increase in AR for } 60 \\
\text { trading days after a firm is added to the index; } \\
\text { however, there is a statistically insignificant change in } \\
\text { AR after a firm is removed from the index. }\end{array}$ \\
\hline Lourenço et al., (2012) [9] & $\begin{array}{l}\text { Accounting-based valuation } \\
\text { model }\end{array}$ & $\begin{array}{l}\text { The market value of equity } \\
\text { measured by earnings and } \\
\text { book value }\end{array}$ & $\begin{array}{l}\text { CSP expressed by the membership of the } \\
\text { DJSI (2009) }\end{array}$ & $\begin{array}{l}\text { CSP has significant power over market value. } \\
\text { Investors penalize large firms with low CSP. }\end{array}$ \\
\hline $\begin{array}{l}\text { Cheung and Roca (2013) } \\
\text { [24] }\end{array}$ & & Stock returns & $\begin{array}{l}\text { Inclusion in or exclusion from the DJSI } \\
\text { World Index (2002-2010) in the Asia } \\
\text { Pacific stock markets }\end{array}$ & $\begin{array}{l}\text { Inclusion in or exclusion from the DJSI results in a } \\
\text { decrease in price; negative reaction to inclusion in the } \\
\text { DJSI reflects the pessimistic view of sustainability in } \\
\text { the Asia Pacific. }\end{array}$ \\
\hline $\begin{array}{l}\text { Cunha and Samanez } \\
\text { (2013) [25] }\end{array}$ & $\begin{array}{l}\text { Descriptive and inferential } \\
\text { statistical comparison (Sharpe, } \\
\text { Sortino, Treynor, Omega) }\end{array}$ & $\begin{array}{l}\text { Performance of the } \\
\text { sustainability index of } \\
\text { BM\&FBOVESPA (2005 to } \\
\text { 2010) }\end{array}$ & $\begin{array}{l}\text { IBOVESPA (representing the market } \\
\text { portfolio) and other BM\&FBOVESPA } \\
\text { sectoral indices }\end{array}$ & $\begin{array}{l}\text { Sustainable investment has increased liquidity and } \\
\text { low diversifiable risk; however, it cannot achieve } \\
\text { satisfactory financial performance. }\end{array}$ \\
\hline
\end{tabular}


Table 1. Cont.

\begin{tabular}{|c|c|c|c|c|}
\hline Authors & Methodology & Dependent Variable & Independent Variable (s) & Results \\
\hline Nakai et al., (2013) [10] & $\begin{array}{l}\text { Event study and } \\
\text { regression analysis }\end{array}$ & Stock returns & $\begin{array}{l}\text { Inclusion in or exclusion from the } \\
\text { Morningstar SRI index (2003-2010) }\end{array}$ & $\begin{array}{l}\text { While inclusion positively affects share price, the } \\
\text { exclusion does not have a significant impact. Negative AR } \\
\text { in earlier years, positive AR in later years. Positive change } \\
\text { in investors' perceptions regarding CSR activities. }\end{array}$ \\
\hline $\begin{array}{l}\text { Oberndorfer et al., (2013) } \\
\text { [11] }\end{array}$ & $\begin{array}{l}\text { Event study (three-factor } \\
\text { asset pricing model and a } \\
\text { GARCH }(1,1) \text { ) }\end{array}$ & Stock returns & $\begin{array}{l}\text { Inclusion of German firms in the DJ Stoxx } \\
\text { SI and the DJ Sustainability World Index }\end{array}$ & $\begin{array}{l}\text { Inclusion in the DJSI World index has a negative impact } \\
\text { on stock performance. No significant average CAR for } \\
\text { inclusion in the DJSI Stoxx index. Inclusion in a more } \\
\text { visible sustainability index may have larger negative } \\
\text { impacts. }\end{array}$ \\
\hline Hawn et al., (2014) [34] & Event study & Stock returns & Additions to and deletions from the DJSI & $\begin{array}{l}\text { Firms with a lower performance benefit more from } \\
\text { gaining status and pay higher penalties for losing it; firms } \\
\text { with higher market legitimacy benefit less from increased } \\
\text { social legitimacy and lose less from decreased social } \\
\text { legitimacy. }\end{array}$ \\
\hline Sudha (2015) [26] & $\begin{array}{l}\text { GARCH models to } \\
\text { analyze the conditional } \\
\text { volatility }\end{array}$ & $\begin{array}{l}\text { Performance of the } \\
\text { sustainability index of } \\
\text { India (S\&P ESG India } \\
\text { Index) }\end{array}$ & Nifty and the S\&P CNX 500 indices & $\begin{array}{l}\text { Daily compounded returns of the ESG India index are not } \\
\text { statistically different from those of the Nifty or the CNX } \\
500 \text {; however, annualized returns of the ESG India index } \\
\text { have been better than the returns of the other two indices. } \\
\text { The ESG India index has been less volatile compared to } \\
\text { the Nifty during the period. }\end{array}$ \\
\hline $\begin{array}{l}\text { Van Stekelenburg et al., } \\
\text { (2015) [27] }\end{array}$ & Event study & Stock returns & $\begin{array}{l}\text { Inclusion in and exclusion from the DJ } \\
\text { Sustainability Europe Index (2009-2013) }\end{array}$ & $\begin{array}{l}\text { The addition to the index temporarily increases its price } \\
\text { for one trading day after the announcement, and removal } \\
\text { from the index temporarily decreases its price between } \\
\text { five and ten trading days after the effective change date. }\end{array}$ \\
\hline Joshi et al., (2017) [29] & Event study & Stock returns & $\begin{array}{l}\text { Inclusion in or exclusion from the DJSI } \\
\qquad(2002-2011)\end{array}$ & $\begin{array}{l}\text { There is a negative reaction to both DJSI inclusion and } \\
\text { exclusion, indicating that the market assesses the benefits } \\
\text { of sustainability efforts only in the context of costs. }\end{array}$ \\
\hline Çıtak et al., (2018) [35] & Event study & Stock returns & $\begin{array}{l}\text { Inclusion in the BIST SI for } 50 \text { BIST firms } \\
\qquad(2015-2016)\end{array}$ & $\begin{array}{l}\text { There is no significant difference between returns of those } \\
50 \text { BIST firms included and not included in the index, } \\
\text { except for the interval of } 0 \text { to }+4 \text { days to }+10 \text { days, where } \\
\text { there is significant CAR for the firms included in the BIST } \\
\text { SI. }\end{array}$ \\
\hline Hayward (2018) [30] & Event study & Stock returns & $\begin{array}{l}\text { Addition to or deletion from the DJSI } \\
\text { North America (2005-2016) }\end{array}$ & $\begin{array}{l}\text { While deletion from the index has a negative and } \\
\text { statistically significant temporary impact on the price for } \\
\text { seven trading days following the change date, addition to } \\
\text { the index has a positive and statistically significant } \\
\text { temporary impact on the price for two trading days } \\
\text { following the announcement date. }\end{array}$ \\
\hline
\end{tabular}




\subsection{CS Performance and Stock Return}

The inclusion in an SI, such as the BIST SI may be a reliable signal for a higher intensity of ESG activities and may affect investor preferences creating an impact on price performance. Thus, one may expect that additions to the SI may create a temporary price pressure and can cause short-run deviations in return, which puts higher CS performance into question [36]. This is relevant especially for evaluating the efficiency of CSR and has wider implications for asset managers who can expect abnormal returns by investing in companies that exhibit high CSR in their respective scores and holding the stocks for a more extended period [37].

Furthermore, activities that aim to increase CS performance can be expensive and non-productive, serving solely social goals, and the investors may observe its benefits in the distant future. We may apply this argument to the inclusion of the SI. That is, the costs of the ESG activities may outweigh their financial benefits so that the main principle of shareholder wealth maximization can be violated and CS performance may result in reduced profits, decreasing company values, or competitive disadvantages [38].

This view is also endorsed by the corporate governance (CG) theory $[39,40]$. In a narrow framework, CG includes measures, which assure that investors acquire a satisfactory yield for their investments. Thus, only if CG structures are properly designed, management will concentrate on profit maximization. Accordingly, one can argue that the consideration of stakeholder goals as a motivation for corporate sustainability activities, and eventually the inclusion in an SI extends the latitude of management, which could be misused for only maximizing the utility of managers [11].

Hypothesis 1. The inclusion of firms in BIST SI has a positive effect on stock return.

\subsection{CS Performance and Total Risk}

The second hypothesis rests on two main arguments. First, it is based on the empirical evidence that stocks with a high level of ESG rating have ceteris paribus a lower total risk than otherwise identical stocks with the same systematic risk but a lower ESG rating [41,42]. This empirical evidence is theoretically intuitive as companies with a substantial disregard for ESG criteria expose themselves to considerable risks of environmental disasters, consumer boycotts, or other costly reputation scandals [43]. Indeed, Godfrey [44] found that corporate ESG actions allow companies to accumulate insurance like goodwill, which shields them from adverse market reactions in cases of legal, public, or regulatory actions against them. Hence, a stock's ESG rating is negatively associated with its specific risk suggesting that highly ESG rated stocks have a lower total risk than identical stocks with low ESG rating (but the same systematic risk). The same goes true for the stock return volatility. That is, companies that perform better in ESG factors are less risky than the rest of the companies in the same industry [45].

The second argument is based on diversification. We expect that the inclusion of ESG standards into investment processes increases portfolio diversification through a reduction of the average stock's specific risk. This approach implies that active investment managers should consider the inclusion of ESG measures in their portfolio management process to improve their risk management. Based on this discussion, the following hypothesis is proposed:

Hypothesis 2. The inclusion of firms in BIST SI decreases the total risk of stocks.

\subsection{CS Performance and Gaining Access to Capital}

Foreign ownership usually forces companies to reveal more information. Companies, which have diversified investors across international markets, have more diverse stakeholder groups. Thus, they face potentially stronger and more varied attacks, leading them to voluntarily disclose more 
information to avoid damage to their reputation. Therefore, the relationship between sustainability disclosures and foreign ownership is essentially a balancing act between pressures from local and foreign investors. Chapple and Moon [46] found that companies with foreign ownership are more likely to report. Since there may be a positive or negative relationship between the level of foreign ownership and sustainability performance relying on how the benefits and costs add up for the company, we suggest that the share of foreign investors from countries with strong instead of weak norms will be positively affected if a company's sustainability performance level improves. This issue is particularly important for BIST since on average foreign investors own $65 \%$ of the free float shares for the last two decades. Hence, we assume the following hypothesis:

Hypothesis 3a. The inclusion of firms in the BIST SI has a positive effect on the level of foreign ownership.

A more focused analysis of the importance of ESG metrics accounts for investor type. Of particular interest are institutional investors. They are more aware of the impact that reputational attacks on companies may have on institutional portfolio returns [47]. Sometimes institutional ownership may not be positively associated with ESG strengths but are negatively associated with ESG weaknesses [48]. Institutional investors compete for capital, and lower performance will influence fund flows increasing the significance of financial returns. They are also exposed to social norms as they need to network and raise capital locally and are mindful of local ESG standards. Institutional ownership is usually positively related to ESG performance since institutions are motivated by both financial and social gains. Drawing on evidence from 41 countries, Dyck et al. [49] reveal that institutional investors raise companies' ESG performance when they come from countries with a strong community belief in the significance of ESG issues. Thus, these institutional investors transfer their social norms around the world.

Additionally, we analyze institutional investors because these shareholders own and vote the majority of the world's equity capital. Especially those institutional investors that are signatories of the United Nations Principles for Responsible Investments (UN PRI) convey their preferences for firms getting improved ESG scores and committing to position themselves at the medium to a high level of ESG activism. Based on this discussion and confirming evidence, the following hypothesis is proposed:

Hypothesis 3b. The inclusion of firms in the BIST SI has a positive effect on the level of institutional ownership.

\subsection{CS Performance and Resilience to Crises}

A growth in perceived ESG activities may enhance a company's reputation and allow it to exchange costly explicit claims for less costly implicit charges, whereas if stakeholders identify a decline in ESG activities, this may increase explicit claims. This outcome may be interpreted as a part of the social impact hypothesis. Since there is usually a direct connection between reputation and market performance, one may expect that the stock price of a company included in the SI will be less impacted by a crisis compared to other companies not included in the SI. Another potential benefit of being included in the SI is that there is an anticipated decline in the variability of future cash flows, which helps companies to resist potential economic and political crises. This effect may be understood in the frame of the stakeholder theory. Epstein and Schneitz [50] investigated whether a reputation for social responsibility would help to protect companies from shareholder losses. They found evidence for this by testing whether companies included in the KLD Domini Social Index suffered a loss due to the failure of the 1999 Seattle World Trade Organization meetings and noted that companies with a bad reputation for CSR were negatively impacted by the protests. Bouslah et al. [51] came up with a similar outcome. They examined the effects of the 2008-2009 financial crisis on the relationship between a company's risk and social performance for non-financial US companies from 1991 to 2018 and found that social performance decreases volatility during the crisis. 
These findings support the view that ESG activities aid a company to build reputational capital, which improves its ability to negotiate more attractive deals with governments and suppliers, to charge premium prices for its products, and to reduce its cost of capital all of which help it to deal with price pressure that may stem from the crisis. Thus, the following hypothesis is assumed:

Hypothesis 4. The inclusion of firms in the BIST SI increases their resilience to crises.

\section{Research Method}

\subsection{Sample}

Figure 1 shows the research framework. Our sample frame comprises the companies listed in the BIST 100 benchmark index. BIST is a self-regulatory entity in the form of a joint-stock company that covers all the exchanges operating in Turkey. As of 2017, 411 companies were listed on the BIST, and the market capitalization was USD 230 billion. A wide variety of instruments are traded on the BIST, including stocks, exchange-traded funds (ETFs), treasury bills, corporate bonds, government bonds, sukuk, foreign securities, derivative instruments, and precious metals.

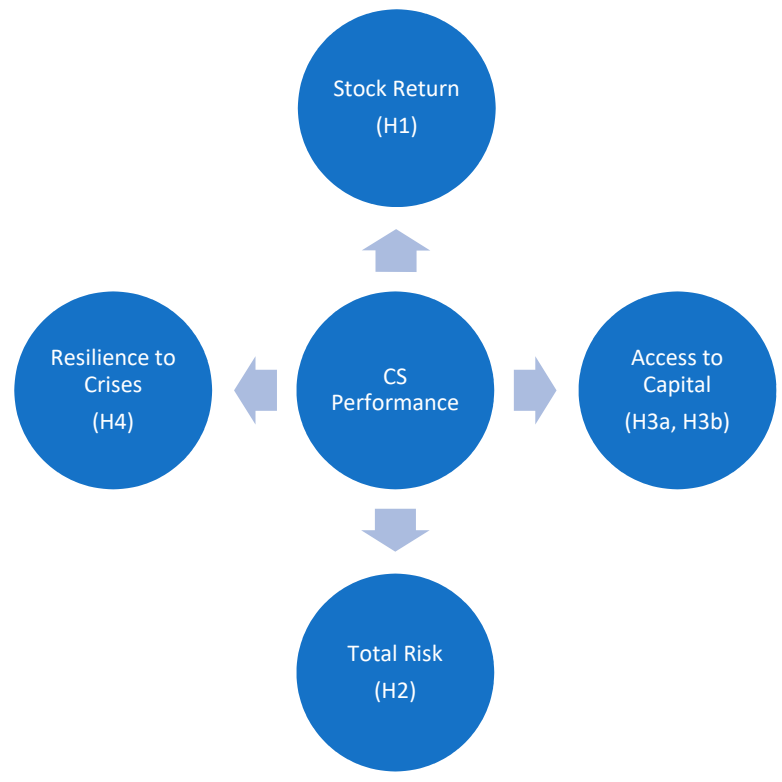

Figure 1. Research framework.

The BIST SI provides a benchmark for companies with high performance in corporate sustainability and increases awareness, knowledge, and practice of sustainability in Turkey. In addition, the BIST SI is a platform for institutional investors to show their commitment to companies managing ESG issues with high performance. For this purpose, in 2013, BIST signed a cooperation agreement with a third party, Ethical Investment Research Services Limited (EIRIS), to create BIST SI. By this agreement, EIRIS conducts company screening and assesses companies listed on BIST based on international sustainability criteria.

BIST SI was launched in 2014. The relative weight of each constituent company is capped at 15 percent. There is one index period for BIST SI, November-October. EIRIS assessed constituent companies of the BIST 30 Index in 2014, and constituent companies of the BIST 50 Index in 2015. Starting from 2016, EIRIS evaluated both companies included in the BIST 50 Index and volunteer companies from the BIST 100 Index. The firms included in the BIST SI over the 2014-2017 period are shown in Appendix A Table A1. 
To be included in the BIST SI, companies should perform over the threshold for each group of criteria in policy, management, and reporting. Criteria groups include several sustainability parameters such as environmental pollution, employee relations, human rights, natural resources use, equal opportunities, biodiversity, product safety, shareholder capital and rights, board and management information and remuneration, corruption, and business ethics.

Table 2 shows the variations in the composition of the BIST SI sample over the period 2014-2017. BIST began to calculate the index on 4 November 2014, with the announcement of 15 companies. On 23 October 2015, BIST announced the new list of companies with 14 new firms. On 24 October 2016, 14 new firms were included, and one firm (SAFGY) was excluded from the index. Finally, on 27 October 2017, five new firms were added to, and three firms (ADEL, GLYHO, and ISGYO) were excluded from the index, leaving 44 firms.

Table 2. Composition of the BIST SI (2014-2017).

\begin{tabular}{ccccc}
\hline Number of Firms & $\mathbf{2 0 1 4}$ & $\mathbf{2 0 1 5}$ & $\mathbf{2 0 1 6}$ & $\mathbf{2 0 1 7}$ \\
\hline Total firms & 15 & 29 & 42 & 44 \\
Included firms & 15 & 14 & 14 & 5 \\
Excluded firms & 0 & 0 & 1 & 3 \\
\hline
\end{tabular}

Source: BIST.

\subsection{Variable Definitions and Measurement}

The following variables are used in this study: CS performance, stock returns, total risk, foreign ownership, institutional ownership, and resilience to crises. The data for these firms are compiled from BIST and Central Registry Agency (MKK), which is the central securities depository for capital market instruments.

CS performance is measured by a dichotomous variable where 1 denotes inclusion in the BIST SI and 0 otherwise.

Stock return is calculated as the logarithmic change in the price of the stock compared with the closing price of the previous day.

The total risk is calculated as the standard deviation of the hundred-day returns before and after entering the index.

Foreign ownership is measured using the percentage of foreign investor shares to total shares based on data compiled from the Public Disclosure Platform in Turkey.

Institutional ownership is computed using the percentage of institutional investor shares to total shares again based on data from the Public Disclosure Platform.

Resilience to crises is measured by the effects of the recently failed coup d'état in Turkey on stock returns. This failed coup d'état, which took place on 15 July 2016 in the form of an armed assault by a faction within the Turkish military against state institutions, including the Turkish government has had severe economic and political effects in Turkey. To investigate the link between the sample companies' CS performance and their resilience to the effects of such a serious crisis, two portfolios for BIST 100 companies are constructed. The first portfolio is composed of companies included in BIST SI, while the second portfolio includes companies not included in BIST SI. The variables and their definitions, along with their sources are reproduced in Appendix B Table A2.

\subsection{Data Analysis}

An event study analysis is adopted to investigate the effect of the announcement on companies' market value. One underlying assumption of the event study is that the market processes information about the event in an efficient and unbiased manner. Thus, one can see the effect of the event on prices. In this study, we defined several events: inclusion in and exclusion from the BIST SI; the impact of the failed coup d'état attempt on BIST SI firms, and others. 
We identified two event dates for each year: the announcement date, or publication of the annual index review (the new composition of the BIST SI) and the effective date, or date on which the new index was effectively released to the market. Table 3 provides information about the event dates. Considering these two dates, we analyzed whether or not the market incorporated the information related to the event. However, as pointed out by Ortas and Moneva [12], we expected that the market would react, if at all, on the announcement date.

Table 3. Event and samples.

\begin{tabular}{clcc}
\hline Sample & Event & Publication Date & Release of the New Index \\
\hline 1 & Included companies-2014 review & 4 November 2014 & 04 November 2014 \\
2 & Included companies-2015 review & 23 October 2015 & 02 November 2015 \\
3 & Included companies-2016 review & 24 October 2016 & 01 November 2016 \\
4 & Included companies-2017 review & 27 October 2017 & 01 November 2017 \\
\hline
\end{tabular}

Source: Borsa Istanbul.

For each review of the index, three events are analyzed: inclusion in the BIST SI, exclusion from the index, and the behavior of all companies in the index. Since there are very few exclusions from the index, this makes robust conclusions almost impossible. That is, it is likely that the estimation results may have been influenced by single company characteristics.

We then analyze the evolution of $A R$ three trading days before the announcement date, including the announcement date itself-I.e., days -3 to 0 - And ten trading days after the announcement date-I.e., days +1 to +10 . To account for the return patterns of new entrants before their inclusion in the index, we first estimate a simple market model for each of the included stocks during the 100 trading day, from $T=-110$ to $T=-10$. Using this window, we expect the $C A R$ for a given stock over the test period.

We analyze the data for each year from 2014 to 2017. We acquire the daily stock price data for AR calculations from the BIST. We calculate the daily returns for stock prices as the logarithmic change in the value of the stock compared with the previous day's closing value according to the following formula:

$$
r_{i, t}=\log \left(P_{i, t} / P_{i, t-1}\right)
$$

where $r_{i, t}$ stands for the return on the stock $i$ at date $t$, while $P_{i, t}$ and $P_{i, t-1}$ denote the daily closing prices of stock $i$ at dates $t$ and $t-1$, respectively.

We utilize the market model to estimate the expected returns of individual stocks for the event windows.

$$
E\left(r_{i, t}\right)=\alpha_{i}+\beta_{i} r_{m, t}+\varepsilon_{i, t}
$$

The formula assumes a linear relationship between the individual stock returns, $r_{i, t}$ and the market return, which is denoted by $r_{m, t}$. We use BIST 100 index returns as the proxy for market return. After estimating the expected returns for the event window day, we calculate the $A R$ of each stock for each day by subtracting the expected returns from the actual returns. Hence:

$$
A R_{i, t}=r_{i, t}-E\left(r_{i, t}\right)
$$

Based on the $A R$ for each of the event window days, we compute $C A R$ covering the whole event period for each stock.

$$
C A R_{i}=\sum_{t=0}^{T} A R_{i, t}
$$


To evaluate whether inclusion in the index has a significant effect on prices, we take the average of the $C A R$ of individual stocks to calculate the average cumulative abnormal returns ( $A C A R$ ).

$$
A C A R_{0, T}=\frac{\sum_{i=1}^{N} C A R_{i}}{N}
$$

Accordingly, the variance for $A C A R_{0, T}$ can be calculated as the average variance of the $C A R$ of individual stocks.

$$
\operatorname{VAR}\left(\operatorname{ACAR}_{(0, T)}\right)=\frac{1}{N^{2}} \hat{\sigma}_{0, T}^{2}
$$

Finally, to assess whether the calculated ACAR is statistically significant from zero, we compute the following test statistic with normal distribution:

$$
T=\frac{A C A R_{0, T}}{\sqrt{V A R\left(A C A R_{0, T}\right)}} \approx N(0,1)
$$

\section{Empirical Findings and Discussion}

We adopted market model to calculate abnormal returns to test our study's hypotheses due to its potential improvement over the constant mean return model. By eliminating the portion of the return that is related to variation in the market's return, the variance of the abnormal return is reduced, which in turn can lead to an increased ability to detect event effects. To further test the sensitivity of the results, we also utilized the mean adjusted and market adjusted models. The results of these two models (not reported here) are found to be in line with the market model. Thus, we adhered to the market model in line with the Cable and Holland's [52] approach.

To test Hypothesis 1, we conducted the analysis for each year. Tables 4-7 provide the summary statistics for $A R$ and $C A R$ from 2014 to 2017. The results show that there is no statistically significant result for 2014 before and after the announcement date (AD), except three days after the AD, which may be interpreted as a temporary reaction. We also observe similar results for 2015. Although the AR are negative most of the time after the $\mathrm{AD}$, they are not statistically significant for new entrants or existing ones.

Table 4. Descriptive statistics for AR and CAR (2014).

\begin{tabular}{ccccc}
\hline \multicolumn{5}{c}{ Index Inclusion } \\
\hline Days & AR & T-Value & CAR & T-Value \\
\hline Day-3 & 0.0009 & 0.2406 & 0.0031 & 0.4175 \\
Day-2 & -0.0016 & -0.9004 & 0.0022 & 0.3317 \\
Day-1 & 0.0020 & 0.4443 & 0.0038 & 0.6030 \\
Day 0 & 0.0018 & 0.4578 & 0.0018 & 0.4578 \\
Day 1 & -0.0019 & -0.6005 & -0.0001 & -0.0270 \\
Day 2 & 0.0047 & 0.9120 & 0.0046 & 0.5611 \\
Day 3 & 0.0090 & $2.5619 *$ & 0.0136 & 1.9098 \\
Day 4 & -0.0021 & -0.3973 & 0.0114 & 1.0496 \\
Day 5 & -0.0007 & -0.2407 & 0.0107 & 1.2136 \\
Day 6 & -0.0019 & -0.4970 & 0.0088 & 0.9258 \\
Day 7 & 0.0023 & 0.5093 & 0.0111 & 0.8725 \\
Day 8 & -0.0023 & -0.7362 & 0.0088 & 0.8187 \\
Day 9 & 0.0034 & 0.8301 & 0.0123 & 1.2996 \\
Day 10 & -0.0020 & -0.5377 & 0.0103 & 0.9044 \\
\hline \multicolumn{5}{c}{$p<0.05}$. \\
\end{tabular}


Table 5. Descriptive statistics for AR and CAR (2015).

\begin{tabular}{ccccccccc}
\hline & \multicolumn{3}{c}{ Index Inclusion (New Firms) } & \multicolumn{3}{c}{ Index Inclusion (All Firms) } \\
\hline Days & AR & T-Value & CAR & $\boldsymbol{T}$-Value & AR & T-Value & CAR & $T$-Value \\
\hline Day-3 & 0.0077 & 0.6135 & 0.0055 & 0.5047 & 0.0036 & 0.5569 & 0.0034 & 0.5628 \\
Day-2 & -0.0019 & -0.6156 & -0.0022 & -0.4034 & 0.0015 & 0.7777 & -0.0003 & -0.0822 \\
Day-1 & -0.0008 & -0.2248 & -0.0003 & -0.0785 & -0.0012 & -0.6389 & -0.0018 & -0.6824 \\
Day 0 & 0.0004 & 0.1496 & 0.0004 & 0.1496 & -0.0006 & -0.3214 & -0.0006 & -0.3214 \\
Day 1 & 0.0012 & 0.2976 & 0.0016 & 0.2984 & 0.0012 & 0.5382 & 0.0006 & 0.1999 \\
Day 2 & -0.0032 & -0.7228 & -0.0016 & -0.2927 & -0.0026 & -0.8273 & -0.0019 & -0.4992 \\
Day 3 & -0.0035 & -0.6628 & -0.0052 & -0.6557 & -0.0025 & -0.8794 & -0.0045 & -0.9356 \\
Day 4 & -0.0050 & -1.2841 & -0.0102 & -1.1526 & -0.0019 & -0.5721 & -0.0064 & -1.1424 \\
Day 5 & 0.0026 & 0.3104 & -0.0076 & -0.9682 & 0.0054 & 1.0904 & -0.0010 & -0.1767 \\
Day 6 & -0.0005 & -0.1254 & -0.0081 & -0.9826 & 0.0015 & 0.6186 & 0.0006 & 0.0957 \\
Day 7 & -0.0026 & -0.8225 & -0.0107 & -1.0644 & -0.0025 & -1.1170 & -0.0019 & -0.2854 \\
Day 8 & 0.0066 & 1.1517 & -0.0041 & -0.4282 & 0.0020 & 0.5925 & 0.0000 & 0.0061 \\
Day 9 & -0.0008 & -0.1816 & -0.0049 & -0.4358 & -0.0002 & -0.0924 & -0.0002 & -0.0272 \\
Day 10 & 0.0080 & $3.2592 *$ & 0.0031 & 0.2850 & 0.0052 & $2.4488 *$ & 0.0050 & 0.7305 \\
\hline
\end{tabular}

Table 6. Descriptive statistics for AR and CAR (2016).

\begin{tabular}{ccccccccccccc}
\hline & \multicolumn{4}{c}{ Index Inclusion (New Firms) } & \multicolumn{3}{c}{ Index Inclusion (All Firms) } & \multicolumn{3}{c}{ Index Exclusion (SAFGY) } \\
\hline Days & AR & T-Value & CAR & T-Value & AR & T-Value & CAR & T-Value & AR & T-Value & CAR & T-Value \\
\hline Day-3 & 0.0008 & 0.1460 & -0.0073 & -1.0326 & -0.0009 & -0.4394 & -0.0080 & $-2.2322 *$ & 0.0042 & 0.1642 & -0.0061 & -0.4610 \\
Day-2 & -0.0073 & $-3.8756^{*}$ & -0.0081 & -1.7559 & -0.0042 & $-2.5849^{*}$ & -0.0071 & $-2.6884^{*}$ & -0.0137 & -0.5408 & -0.0103 & -0.6601 \\
Day-1 & -0.0022 & -0.6801 & -0.0007 & -0.1790 & -0.0018 & -1.1951 & -0.0029 & -1.4698 & -0.0111 & -0.4382 & 0.0034 & 0.1881 \\
Day 0 & 0.0014 & 0.6043 & 0.0014 & 0.6043 & -0.0011 & -0.8328 & -0.0011 & -0.8328 & 0.0145 & 0.5703 & 0.0145 & 0.5703 \\
Day 1 & -0.0038 & -1.3503 & -0.0023 & -0.6841 & -0.0010 & -0.7762 & -0.0021 & -1.2593 & -0.0108 & -0.4253 & 0.0037 & 0.2055 \\
Day 2 & -0.0037 & -1.0892 & -0.0061 & -1.2274 & -0.0005 & -0.2906 & -0.0026 & -1.0470 & -0.0019 & -0.0753 & 0.0018 & 0.1370 \\
Day 3 & 0.0014 & 0.7223 & -0.0047 & -0.9081 & 0.0019 & 1.1462 & -0.0007 & -0.2383 & -0.0093 & -0.3736 & -0.0075 & -0.6490 \\
Day 4 & -0.0041 & -1.5068 & -0.0088 & -1.9431 & -0.0029 & $-2.2428 *$ & -0.0036 & -1.2530 & -0.0105 & -0.4282 & -0.0180 & -1.6741 \\
Day 5 & -0.0026 & -0.5981 & -0.0114 & $-2.4574^{*}$ & -0.0041 & $-2.0879 *$ & -0.0077 & $-2.5585^{*}$ & 0.0090 & 0.3690 & -0.0090 & -0.8245 \\
Day 6 & -0.0112 & $-2.0067^{*}$ & -0.0226 & $-3.1026^{*}$ & -0.0030 & -1.0804 & -0.0107 & $-2.7011^{*}$ & -0.0051 & -0.2209 & -0.0142 & -1.4054 \\
Day 7 & 0.0017 & 0.6642 & -0.0209 & $-2.5375^{*}$ & 0.0013 & 0.7012 & -0.0094 & $-2.2792^{*}$ & 0.0016 & 0.0704 & -0.0125 & -1.3326 \\
Day 8 & -0.0042 & -0.7497 & -0.0251 & $-2.3599^{*}$ & -0.0002 & -0.0774 & -0.0096 & $-2.0125^{*}$ & -0.0076 & -0.3912 & -0.0201 & $-2.2298 *$ \\
Day 9 & -0.0076 & $-2.5315 *$ & -0.0327 & $-2.7006^{*}$ & -0.0020 & -0.8550 & -0.0116 & $-1.9867^{*}$ & 0.0322 & 1.7872 & 0.0120 & 0.8715 \\
Day 10 & 0.0079 & $2.5276^{*}$ & -0.0248 & $-2.0228^{*}$ & -0.0008 & -0.3637 & -0.0124 & $-2.1582 *$ & -0.0114 & -0.6451 & 0.0007 & 0.0499 \\
\hline
\end{tabular}

${ }^{*} p<0.05$.

Table 7. Descriptive statistics for AR and CAR (2017).

\begin{tabular}{|c|c|c|c|c|c|c|c|c|c|c|c|c|}
\hline \multirow[b]{2}{*}{ Days } & \multicolumn{4}{|c|}{ Index Inclusion (New Firms) } & \multicolumn{4}{|c|}{ Index Inclusion (All Firms) } & \multicolumn{4}{|c|}{$\begin{array}{c}\text { Index Exclusion (ADEL, GLYHO, } \\
\text { ISGYO) }\end{array}$} \\
\hline & AR & $T$-Value & CAR & $T$-Value & AR & $T$-Value & CAR & $T$-Value & AR & $T$-Value & CAR & $T$-Value \\
\hline Day-3 & 0.0096 & 1.0274 & 0.0117 & 1.1149 & 0.0010 & 0.4227 & 0.0029 & 0.7923 & 0.0015 & 0.2784 & -0.0032 & -1.1609 \\
\hline Day-2 & 0.0009 & 0.2085 & 0.0022 & 0.5851 & 0.0012 & 0.5230 & 0.0019 & 0.6581 & -0.0044 & $-4.2756^{*}$ & -0.0046 & -1.8385 \\
\hline Day-1 & 0.0095 & $3.3807^{*}$ & 0.0013 & 0.2174 & 0.0024 & 1.1010 & 0.0007 & 0.2679 & -0.0009 & -0.2357 & -0.0002 & -0.1560 \\
\hline Day 0 & -0.0082 & -1.6166 & -0.0082 & -1.6166 & -0.0017 & -0.8663 & -0.0017 & -0.8663 & 0.0006 & 0.2577 & 0.0006 & 0.2577 \\
\hline Day 1 & 0.0035 & 0.4974 & -0.0048 & -0.9439 & 0.0017 & 0.9148 & 0.0000 & 0.0026 & 0.0053 & 0.8471 & 0.0059 & 0.8736 \\
\hline Day 2 & 0.0002 & 0.0286 & -0.0046 & -0.4415 & 0.0022 & 0.4939 & 0.0022 & 0.3941 & -0.0371 & -3.3603 * & -0.0312 & -1.9579 \\
\hline Day 3 & -0.0091 & -1.1115 & -0.0137 & -1.2101 & -0.0061 & -1.8675 & -0.0039 & -0.5083 & -0.0110 & -1.1412 & -0.0422 & -1.8053 \\
\hline Day 4 & 0.0030 & 0.3618 & -0.0107 & -0.6723 & -0.0020 & -0.4415 & -0.0059 & -0.9960 & -0.0079 & -1.3298 & -0.0501 & -1.8383 \\
\hline Day 5 & -0.0051 & -1.1180 & -0.0158 & -1.2054 & 0.0009 & 0.2546 & -0.0051 & -0.8081 & 0.0149 & 1.2437 & -0.0352 & -1.5483 \\
\hline Day 6 & -0.0057 & -0.6023 & -0.0214 & -0.9822 & -0.0018 & -0.5796 & -0.0068 & -0.9130 & -0.0143 & $-6.1448 *$ & -0.0494 & -2.1093 * \\
\hline Day 7 & 0.0061 & 1.4144 & -0.0154 & -0.7270 & 0.0059 & 1.8110 & -0.0009 & -0.1005 & 0.0131 & 4.8840 * & -0.0364 & -1.5056 \\
\hline Day 8 & 0.0048 & 0.4898 & -0.0105 & -0.6167 & 0.0043 & 1.3438 & 0.0034 & 0.3668 & 0.0332 & 0.9724 & -0.0031 & -0.0715 \\
\hline Day 9 & 0.0046 & 0.5437 & -0.0060 & -0.3233 & 0.0058 & 1.7798 & 0.0092 & 0.9572 & 0.0140 & 1.0772 & 0.0109 & 0.2055 \\
\hline Day 10 & -0.0028 & -0.6248 & -0.0087 & -0.4713 & 0.0002 & 0.0692 & 0.0094 & 0.8974 & 0.0077 & 1.3062 & 0.0186 & 0.3188 \\
\hline
\end{tabular}


The year 2016 shows negative and statistically significant results four days after the AD, and this persists until ten days for the entire group of companies in the BIST SI (including existing firms and new entrants) as well as for only new entrants. Hence, it seems that there is a post-announcement drift for 2016. When we analyze the volunteer firms (ADEL, GLYHO, ISGYO, KORDS, NETAS, TTRAK, VESBE, and ZOREN), we obtain similar results. As only one company is excluded from the index, it would be almost impossible to draw a conclusion. As for 2017, we are not able to find any significant $A R$ and $C A R$ values for all three groups, including new entrants, exits, and all companies.

Based on these findings, we conclude that the inclusion of companies in the BIST SI has neither a significant negative nor a positive impact on stock returns. Thus, no support is found for Hypothesis 1 . The results, however, tend to be in line with the argument of the price pressure hypothesis, which posits that the inclusion announcement does not carry information. Thus, investors do not actively reward inclusion in or punish exclusion from the index, and the market needs time to elaborate on the sustainability policies of the BIST companies. This finding conforms to those of previous studies [11,12].

To test Hypothesis 2, we measured the impact of inclusion in BIST SI on total risk, as strong CS performance is expected to decrease both systematic and idiosyncratic risks of a company. Table 8 reports the test results for change in systematic risk (beta) and total risk (standard deviation) before and after the AD. We conducted a paired-sample $T$-test and Wilcoxon signed-rank test to compare the risks before and after SI inclusion. Wilcoxon's signed-rank test results are insignificant for both total risk and systematic risk. There is a significant difference in the total risk between before SI inclusion and after SI inclusion ( $T$-value $=2.055, p<0.05$ ). This finding supports Hypothesis 2 , confirming a significant relationship between CS performance and total risk in that the inclusion of companies in BIST SI decreases the total risk of stocks. This finding also corroborates that of Lameria et al.'s [53] study on Brazilian capital markets. We also conducted a paired-sample t-test to compare the beta before and after the BIST SI inclusion. No significant difference was found in the beta values before and after the BIST SI inclusion $(T$-value $=0.781, p=0.439)$, suggesting that index inclusion does not affect beta, a finding which is also in line with that of Godfrey [44]. These findings are self-explanatory since companies that disregard sustainability activities expose themselves to considerable risks of environmental disasters, consumer boycotts, social disputes, or other costly reputation matters. These adverse market reactions negatively affect the total risks of the companies.

Table 8. Total risk and systematic risk (beta) before and after BIST SI inclusion.

\begin{tabular}{|c|c|c|c|c|c|c|}
\hline & \multicolumn{2}{|c|}{ Mean } & \multicolumn{2}{|c|}{ Standard Deviation } & \multicolumn{2}{|c|}{ Test Statistics ( $p$-Value) } \\
\hline & Before & After & Before & After & $T$-Value & $\begin{array}{c}\text { Wilcoxon } \\
\text { Signed-Rank Test }\end{array}$ \\
\hline Total risk (St. Dev.) & 0.020 & 0.018 & 0.006 & 0.004 & $2.055(0.046) *$ & $-1.611(0.107)$ \\
\hline Systematic risk (Beta) & 0.9220 & 0.8922 & 0.3424 & 0.3558 & $0.781(0.439)$ & $-705(0.481)$ \\
\hline Number of stocks & & & & 46 & & \\
\hline
\end{tabular}

To test the impact of the inclusion of companies in the BIST SI on the level of both foreign ownership and institutional ownership as denoted by Hypotheses $3 a$ and $3 b$, respectively, we used data on the third and fourth quarters, since the announcement date and effective date for the BIST SI are within the fourth quarter.

No support is, however, found for Hypothesis 3a. As it is readily apparent from Table 9 that there is no significant difference between before and after BIST SI inclusion $(p>0.1)$ for the foreign ownership level (in percentage terms) based on the T-test and Wilcoxon signed-rank test results. This implies that, in general, foreign investors do not value sustainability in their investments. This may be because foreign investor groups consist of heterogeneous investors. The foreign investor category in Turkey includes not only long-term funds but also short-term speculative investors whose primary goal is only short-term profit. Further, diversity with respect to sustainability challenges in emerging markets 
makes it challenging to identify overarching key sustainability issues. A thorough understanding of each market with its unique challenges is required for a healthy assessment.

Table 9. Foreign and institutional ownership (\%) before and after BIST SI inclusion.

\begin{tabular}{ccccccc}
\hline & \multicolumn{2}{c}{ Mean } & \multicolumn{2}{c}{ Standard Deviation } & \multicolumn{2}{c}{ Test Statistics $(p$-Value) } \\
\cline { 2 - 7 } & Before & After & Before & After & T-Test & $\begin{array}{c}\text { Wilcoxon } \\
\text { Signed-Rank Test }\end{array}$ \\
\hline Foreign ownership & 28.78 & 29.34 & 19.34 & 18.98 & $-0.78(0.4395)$ & $-0.011(0.992)$ \\
$\begin{array}{c}\text { Institutional ownership } \\
\text { Number of stocks }\end{array}$ & 59.32 & 59.57 & 25.69 & 25.48 & $-1.77(0.0825)$ & $-2-212(0.027) *$ \\
\hline & & & & 47 & & \\
\hline & & & &
\end{tabular}

The Wilcoxon signed-rank test results in Table 9 indicate that there is a significant difference in the institutional ownership level (in percentage terms) before- and after-BIST SI inclusion $(p<0.05)$ providing support for Hypothesis $3 b$. This finding also confirms that of Durand et al. [54], who found that sustainability events result in an increase in the percentage of shares held by long-term investors indicative of a trend that institutional investors place more emphasis on CSR-visible firms. Thus, the sustainability index helps to attract institutional investors, seeking international diversification to the local capital markets. One potential explanation may be that these investors are highly exposed to social norms, and they are motivated by both financial and social gains to promote their reputation and to network in international markets for raising capital from faith-conscious investors.

To test Hypothesis 4, we also looked at how companies included in the BIST SI react to a serious crisis compared to those firms not included in the BIST SI. To conduct this analysis, we chose the date of 15 July 2016, when Turkey was subject to a failed coup d'état attempt. We observed that although the companies included in the BIST SI reacted negatively, their reaction was not statistically significant. In contrast, companies that were not included in the BIST SI at that time reacted negatively, and the results were statistically significant for them, showing a post-announcement drift. While Table 10 presents the summary statistics for AR and CAR around the failed coup d'état attempt for companies included in the BIST SI and others, Figure 2 shows the AR and CAR of stocks before and after the failed coup d'état attempt for both companies included in the BIST SI and others. Although the AR and CAR are negative after the event, they are not significant for firms included in the BIST SI, supporting Hypothesis 4. These findings lead us to conclude that firms included in the BIST SI are stronger in handling a crisis compared to other firms not included in the BIST SI. Also, these findings corroborate those of Schnietz and Esptein [32] who contend that a reputation for sustainability protects companies from stock declines related to a crisis. Practicing sustainability activities can build trust and can enhance firms' reputation because these companies can achieve a better understanding of their stakeholders via ESG and can incorporate local communities' needs into their product offerings and services. They may also have strong brand building strategies and are often capable of dealing with difficult circumstances in case of crisis.

Event studies usually assume that the market efficiently updates stock prices as information, which may affect cash flows, becomes available. The absence of an impact on the stock market resulting from a negative or positive change in CS performance, as measured by inclusion in or exclusion from the BIST SI, indicates that CS performance is still not treated as having an impact on firms' future cash flows, and hence their market value. Additionally, a corporate reputation for sustainability protects companies from stock declines associated with severe crises, as in the case of the recently failed coup d'état attempt in Turkey. 
Table 10. The behavior of firms after the failed coup d'état attempt on 15 July 2016.

\begin{tabular}{ccccccccc}
\hline & \multicolumn{3}{c}{ Firms Included in the BIST SI } & \multicolumn{3}{c}{ Other Firms } \\
\hline Days & AR & T-Value & CAR & $T$-Value & AR & $T$-Value & CAR & $T$-Value \\
\hline Day-3 & -0.0019 & -0.8029 & -0.0013 & -0.1957 & -0.0017 & -0.3032 & -0.0034 & -0.5029 \\
Day-2 & 0.0001 & 0.0275 & 0.0006 & 0.1094 & -0.0051 & -1.5350 & -0.0017 & -0.3451 \\
Day-1 & 0.0020 & 0.6509 & 0.0006 & 0.1341 & 0.0022 & 0.6488 & 0.0034 & 0.8126 \\
Day 0 & -0.0014 & -0.5066 & -0.0014 & -0.5066 & 0.0012 & 0.4049 & 0.0012 & 0.4049 \\
Day 1 & -0.0110 & -1.2906 & -0.0124 & -1.4935 & -0.0177 & $-2.3636^{*}$ & -0.0166 & $-1.9865^{*}$ \\
Day 2 & 0.0080 & 1.8057 & -0.0044 & -0.5652 & 0.0129 & $3.6484^{*}$ & -0.0037 & -0.3967 \\
Day 3 & -0.0081 & -1.6863 & -0.0124 & -1.4371 & -0.0095 & $-2.6336^{*}$ & -0.0132 & -1.2803 \\
Day 4 & -0.0010 & -0.2236 & -0.0134 & -1.3146 & -0.0121 & $-2.3715^{*}$ & -0.0253 & $-2.2196^{*}$ \\
Day 5 & 0.0009 & 0.1929 & -0.0125 & -1.2618 & 0.0048 & 1.0542 & -0.0205 & -1.9113 \\
Day 6 & 0.0000 & 0.0035 & -0.0125 & -1.4959 & 0.0161 & $2.9174 *$ & -0.0045 & -0.3142 \\
Day 7 & -0.0024 & -0.8208 & -0.0149 & -1.5811 & 0.0038 & 0.8243 & -0.0007 & -0.0433 \\
Day 8 & 0.0021 & 1.1324 & -0.0128 & -1.3352 & 0.0100 & 1.1682 & 0.0093 & 0.3923 \\
Day 9 & 0.0022 & 0.8386 & -0.0106 & -1.0708 & 0.0014 & 0.4983 & 0.0107 & 0.4798 \\
Day 10 & 0.0025 & 0.7524 & -0.0081 & -0.8443 & 0.0073 & $1.9706 *$ & 0.0180 & 0.8376 \\
\hline
\end{tabular}

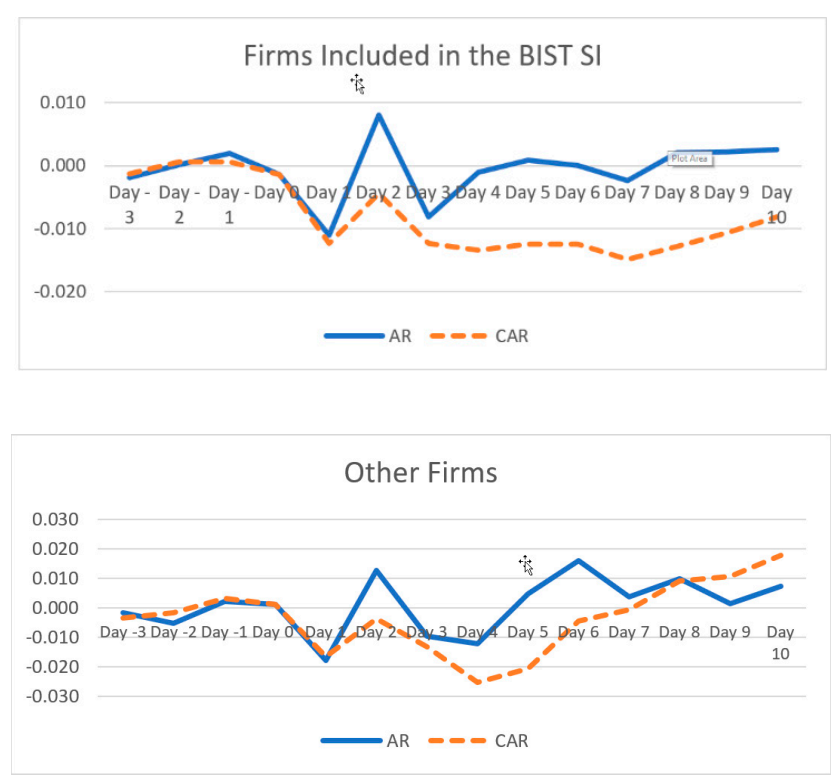

Figure 2. Abnormal returns around the failed coup attempt on 15 July 2016.

\section{Conclusions}

In this study, we analyzed the effect of inclusion in and exclusion from the BIST SI on companies' stocks. The effect was primarily measured in terms of daily stock returns, using event study. We also examined how the betas and risk parameters were influenced by inclusion in the BIST SI. The results indicated that there was no statistically strong evidence of the effect of inclusion in or exclusion from the BIST SI on stock returns and systematic risk (betas) of companies. On the other hand, the results reveal that BIST SI inclusion reduces the total risk of the companies and protects them from stock declines stemming from a severe crisis by improving their resilience compared to other companies not included in the BIST SI.

As the CS performance is closely linked to the need for gaining access to capital in stock markets, we also looked at the relationship between inclusion in BIST SI and foreign and institutional ownership levels. Although we did not find any significant influence of the companies' BIST SI inclusion on the level of foreign ownership, we detected a positive association between BIST SI inclusion and the 
level of institutional ownership. This outcome depicts the increasing attention paid by institutional investors to the companies committing themselves to improve their CS performance.

\subsection{Managerial Implications}

The study's findings suggest that investors in the Turkish capital markets do not yet significantly value CS performance when making their investment decisions. This may stem from the belief that these companies have to bear some costs, which may affect their profitability. Similar to other countries that have experienced the same journey, as Nakai et al. [10] envisage, we expect a positive change in investors' perceptions of Turkey regarding CS activities of firms throughout the years. They will value and reward the inclusion of companies in the BIST SI more in the future as the benefits of CS become more visible to society. Moreover, as findings of the positive links between CS and market-specific company performance measures become more widely known, managers are more likely to pursue CS performance as part of their corporate strategy. As most emerging markets have been increasingly competing with each other to boost capital inflows, company managers should craft corporate strategies that are well aligned with CS practices to attract more institutional investors (e.g., private equity funds). Last but not least, companies should avoid being too reactive or too pro-active in relation to sustainability matters. The companies that are good at this balancing would have a competitive advantage through exploiting opportunities and avoiding threats on more and more sustainability-driven markets, resulting in stronger financial and market performance.

\subsection{Limitations and Future Research}

We should also acknowledge that our study is subject to some limitations. First, this study does not explore the reasons why investors do not penalize firms not viewed as sustainable in response to not being included in the BIST SI. An investigation of the rationale behind investor reactions would make a useful addition to this line of research. This will also provide managers and scholars with much information on how the market impact of sustainability is treated by investors and other stakeholders. As this study is confined to a single emerging market, comparative research involving other emerging markets with some progress in developing sustainability initiatives in their stock markets would provide a further contribution to sustainability research. Finally, we could not empirically test the effect of exclusion from the BIST SI due to the limited number of companies. As the number of entries and exits increases over the years, this may also be a subject of future study.

Author Contributions: Conceptualization and research design, M.K.Y. and M.A.; methodology, formal analysis and data curation, M.A., writing-original draft preparation, M.K.Y.; writing-review and editing, M.K.Y., M.A. and E.T.; visualization and supervision, M.A. and E.T.; discussion of the results, M.K.Y., M.A. and E.T. All authors have read and agreed to the published version of the manuscript.

Funding: This research received no external funding.

Conflicts of Interest: The authors declare no conflict of interest. 


\section{Appendix A}

Table A1. Companies in the BIST SI (2014-2017)

2014

2015

2016 Akbank T.A.Ş. (AKBNK)

Arçelik A.Ş. (ARCLK) $\begin{aligned} \text { Aksa Enerji Uretim A.S. (AKSEN) } \\ \text { Anadolu Efes Biracllk ve Malt Sanayi A S. (AEFES) }\end{aligned}$ ktronik Sanayi ve Ticaret A Solding A S. (KCHOL) Braçlik ve Malt Sanay
Arẹlik A.Ş. (ARCLK) Migros Ticaret A.S. (MGROS)

Petkim Petrokimya Holding A.Ş. (PETKM)

Sabancı Holding A.S. (SAHOL)

TAV Havalimanları Holding A.Ş. (TAVHL)

Tofaş Tưrk Otomobil Fabrikası A.Ş. (TOASO) Tüpraş A.Ş. (TUPRS)

ürk Telekomünikasyon (TTKOM)

Türkiye Garanti Bankası (GARAN)

Yapi ve Kredi Bankası (YKBNK)

Aselsan Elektronik Sanayi ve Ticaret A.S. (ASELS)

Brisa Sabanci Lastik Sanayi ve Ticaret A.Ş. (BRISA) Coca Cola İçecek A.S. (CCOLA)

Doğuş Otomoliv Servis ve ficaret A.Ş. (DOAS)

eğli Demir ve Çelik Fabrikaları A.Ş. (EREGL) Ford Otomotiv Sanayi A.Ş. (FROTO) Koç Holding A.S.s. (KCHOL)

Otokar Otomotiv ve Savunma Sanayi A.Ş. (OTKAR)

Petkim Petrokimya Holding (PETKM)

Sabance Holding A S. (SAHOL) Saf GYO A.S. (SAFGY)

Türkiye Sınai Kalkınma Bankası A.S. (TSKB) TAV Havalimanları Holding (TAVHL)

Tofaş Türk Otomobil Fabrikası A.S. (TOASO) Turkcell Iletişim Hizmetleri (TC
Tüpraş A.S. (TUPRS)

Türk Hava Yolları A.O. (THYAO)

Türk Telekomünikasyon A.Ş. (TTKOM)

Turkiye Garanti Bankası A.Ş. (GARAN) Turkiye is Bankası A.S. (ISCTR) Ülker Bisküvi Sanayi A S. (ULKER)

Vestel Elektronik Sanayi ve Ticaret A.S. (VESTL) Yapı ve Kredi Bankası A.Ş. (YKBNK)
Adel Kalemcilik A.Ş. (ADEL)

Aksa Enerii Üretim A S. (AKSEN)

Anadolu Efes A.Ş. (AEFES)

Arçelik A.Ş. (ARCLK)

Aselsan A.Ş. (ASELS)

oca Cola İ̧eceek A.Ş. (CCOLA)

Doğan Holding A.S.S. (DOHOL)

Doğuş Otomotiv A.Ş. (DOAS)

Ereğli Demir ve Çelik A.গ̧̧. (LREGL)

Ford Otomotiv Sanay A.S.̧. (FROTO)

Iss Gayrımenkul Yatırım Ortaklı̆̆ı (ISGYO)

Koç Holding A.Ş. (KCHOL)

Kordsa Global A.S. (KORDS)

Netaş Telekomünikasyon A.Ş. (NETAS) Pegasus A.S. (PGSUS)

Petkim Petrokimya Holding A.Ş. (PETKM) Sabancı Holding A.Ş. (SAHOL)

TAV Havalimanları Holding A.Ş. (TAVHL) Tekfen Holding A.Ş. (TKFEN)

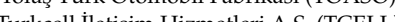
Tüpras A.S. (TUPRS)

Türk Hava Yolları A.O. (THYAO) Türk Traktör A.Ş. (TTRAK)
(TTRS.

Türkiye Garanti Bankası A.Ş. (GARAN) Türkiye Sişe Cam A.S.S. (SISE)

ürkiye Halk Bankası A.Ș. (HALKB)

Türkiye İs Bankası A.Ş. (ISCTR)

Türkiye Sinai Kalkinma Bankası (TSKB)
Türkiye Vakıflar Bankası T.A.O. (VAKBN)

Üe Vakiflar Bankası T.A.O. (VAKB
Ülker Bisküvi A.Ş. (ULKER)

Vestel Elektronik Sanayi A.Ş. (VESTL)

Vestel Beyaz Esya A.Ş. (VESBE)

Yapı ve Kredi Bankası A.Ş. (YKBNK) Zorlu Enerii A.S. (ZOREN)
2017

Akank T A S. (AKBNK)

Aksa Enerii Üretim A.S. (AKSEN)

Anadolu Efes A.SS. (AEFES)

Arçelik A.S. (ARCLK)

Aselsan A.Ş. (ASELS)

Brisa A.Ş. (BRISA)

Çimsa A.Ş. (CIMSA)

Coca Cola işecek A.Ş. (CCOLA)

Doğan Holding A.Ş. (DOHOL)

Dogus Otomotiv A.Ş. (DOAS)

Ereğli Demir ve Çelik A.S. (EREGL)

Koc Holding A. (KCHOL)

Kordsa Global A. (KORDS)

Logo Yazilm A.S. (LOGO)

Migros Ticaret A.S. (MGROS)

Netaş Telekomünikasyon (NETAS)

Otokar Otomotiv A.S. (OTKAR) Pegasus A.Ş. (PGSUS) Petkim A.Ş. (PETKM)

Polisan Holding A.S.. (POLHO) Sabanci Holding A.Ş. (SAHOL) Soda Sanayi A.S. (SODA)
Tat Gıda A.Ş. (TATGD)

TAV Havalimanları Holding (TAVHL) Tekfen Holding A.Ş. (TKFEN) Tüpraş A.Ş. (TUPRS)

Türk Hava Yolları A.O. (THYAO)

Türk Telekomünikasyon A.Ş. (TTKOM) T. Garanti Bankası A.Ş. (GARAN) Türkiye Sișe Cam A.S. (SISE)

Türkiye Halk Bankası A.Ș. (HALKB)

Türkiye İş̧ Bankası A.Ş. (ISCTR) T. Snnai Kalkinma Bankası (TSKB) Türk Traktor A.S.S. (TTRAK) Turkcell lietişim A.Ş. (TRCELL) Türkiye Vastu A.S. (ULKER)

Vestel Elektronik Sanayi AS. (VESTL)

Vestel Beyaz Esya A S. (VESBE) Yapı Kredi Bankası A. S. (YKBNK) Zorlu Enerii A.S. (ZOREN)
Z Kors 


\section{Appendix B}

Table A2. Variables definitions and measurement.

\begin{tabular}{|c|c|c|}
\hline Variable & Measurement & Source \\
\hline CS performance & $\begin{array}{l}\text { The value of } 1 \text { denotes inclusion in } \\
\text { the BIST SI and } 0 \text { otherwise. }\end{array}$ & $\begin{array}{c}\text { Borsa Istanbul } \\
\text { (https://www.borsaistanbul.com/) }\end{array}$ \\
\hline Stock return & $\begin{array}{l}\text { The logarithmic change in the } \\
\text { price of the stock compared to the } \\
\text { closing price of the previous day. }\end{array}$ & $\begin{array}{c}\text { Borsa Istanbul } \\
\text { (https://www.borsaistanbul.com/) }\end{array}$ \\
\hline Total risk & $\begin{array}{l}\text { The standard deviation of the } \\
\text { hundred-day returns before and } \\
\text { after entering the index. }\end{array}$ & $\begin{array}{c}\text { Borsa Istanbul } \\
\text { (https://www.borsaistanbul.com/) }\end{array}$ \\
\hline Foreign ownership & $\begin{array}{l}\text { The percentage of foreign investor } \\
\text { shares to total shares. }\end{array}$ & $\begin{array}{l}\text { Public Disclosure Platform } \\
\text { (http://www.kap.gov.tr) }\end{array}$ \\
\hline Institutional ownership & $\begin{array}{l}\text { The percentage of institutional } \\
\text { investors shares to total shares }\end{array}$ & $\begin{array}{l}\text { Public Disclosure Platform } \\
\text { (http://www.kap.gov.tr) }\end{array}$ \\
\hline Resilience to crises & $\begin{array}{l}\text { The value of } 1 \text { denotes the crisis } \\
\text { and } 0 \text { otherwise. }\end{array}$ & $\begin{array}{l}\text { The failed coup d'état, which took } \\
\text { place on } 15 \text { July } 2016 .\end{array}$ \\
\hline
\end{tabular}

\section{References}

1. Iqbal, N.; Ahmad, N.; Hamad, N.; Bashir, S.; Sattar, W. Corporate social responsibility and its possible impact on firm's financial performance in banking sector of Pakistan. Arab. J. Bus. Manag. Rev. 2014, 3, 150-155.

2. Global Sustainable Investment Alliance. Global Sustainable Investment Review; Global Sustainable Investment Alliance: Washington, DC, USA, 2017.

3. Lee, S.; Kim, I.; Hong, C. Who values corporate social responsibility in the Korean stock market. Sustainability 2019, 11, 5924. [CrossRef]

4. Arribas, I.; Espinos-Vano, M.D.; Garcia, F.; Morales-Banuelos, P.B. The inclusion of socially irresponsible companies in sustainable stock indices. Sustainability 2019, 11, 2047. [CrossRef]

5. Cheung, A.W.K. Do stock investors value corporate sustainability? Evidence from an event study. J. Bus. Ethics 2011, 99, 145-165. [CrossRef]

6. Consolandi, C.; Jaiswal-Dale, A.; Poggiani, E.; Vercelli, A. Global standards and ethical stock indexes: The case of the Dow Jones Sustainability Stoxx Index. J. Bus. Ethics 2009, 87, 185-197. [CrossRef]

7. Curran, M.M.; Moran, D. Impact of the FTSE4Good Index on firm price: An event study. J. Environ. Manag. 2007, 82, 529-537. [CrossRef]

8. Deng, X.; Cheng, X. Can ESG indices improve the enterprises' stock market performance? An empirical study from China. Sustainability 2019, 11, 4765. [CrossRef]

9. Lourenço, I.C.; Branco, M.C.; Curto, J.D.; Eugénio, T. How does the market value corporate sustainability performance? J. Bus. Ethics 2012, 108, 417-428. [CrossRef]

10. Nakai, M.; Yamaguchi, K.; Takeuchi, K. Sustainability membership and stock price: An empirical study using the Morningstar SRI Index. Appl. Financ. Econ. 2013, 23, 71-77. [CrossRef]

11. Oberndorfer, U.; Schmidt, P.; Wagner, M.; Ziegler, A. Does the stock market value the inclusion in a sustainability stock index? An event study analysis for German firms. J. Environ. Econ. Manag. 2013, 66, 497-509. [CrossRef]

12. Ortas, E.; Moneva, J.M. Sustainability stock exchange indexes and investor expectations: Multivariate evidence from DJSI Stoxx. Span. J. Financ. Account. 2011, 11, 395-416. [CrossRef]

13. Wasara, T.M.; Ganda, F. The relationship between corporate sustainability disclosure and firm financial performance in Johannesburg Stock Exchange (JSE) listed mining companies. Sustainability 2019, 11, 4496. [CrossRef]

14. Vives, A.; Wadhwa, B. Sustainability indices in emerging markets: Impact on responsible practices and financial market development. J. Sustain. Financ. Invest. 2012, 2, 318-337.

15. Freeman, R.E. Strategic Management: A Stakeholder Approach; Pitman Publishing: Boston, MA, USA, 1984.

16. Donaldson, T.; Preston, L. The stakeholder theory of the corporation: Concepts, evidence, and implications. Acad. Manag. Rev. 1995, 20, 65-91. [CrossRef] 
17. Friede, G.; Busch, T.; Bassen, A. ESG and financial performance: Aggregated evidence from more than 2000 empirical studies. J. Sustain. Financ. Investig. 2015, 5, 201-233. [CrossRef]

18. Chen, R.C.Y.; Hung, S.W.; Lee, C.H. Does corporate value affect the relationship between corporate social responsibility and stock returns. J. Sustain. Financ. Investig. 2017, 7, 188-196. [CrossRef]

19. McWilliams, A.; Siegel, D. Event studies in management research: Theoretical and empirical issues. Acad. Manag. J. 1997, 40, 626-657.

20. Ramos-Gonzalez, M.M.; Rubio-Andrés, M.; Sastre-Castillo, M.A. Building corporate reputation through sustainable entrepreneurship: The mediating effect of ethical behaviour. Sustainability 2017, 9, 1663. [CrossRef]

21. Dasgupta, S.; Laplante, B.; Mamingi, N. Capital market responses to environmental performance in developing countries. World Bank Policy Res. Work. Pap. 1998, 1909, 1-36.

22. Junior, J.L.R. What Is the Value of Corporate Social Responsibility? An Answer from the Brazilian Sustainability Index. 2009. Available online: http://papers.ssrn.com/sol3/papers.cfm (accessed on 17 June 2019).

23. Fama, E.; French, K. Common risk factors in the returns on stocks and bonds. J. Financ. Econ. 1993, 33, 3-56. [CrossRef]

24. Cheung, A.W.K.; Roca, E. The effect on price, liquidity and risk when stocks are added to and deleted from a sustainability index: Evidence from the Asia Pacific context. J. Asian Econ. 2013, 24, 51-65. [CrossRef]

25. Cunha, F.A.F.; Samanez, C.P. Performance analysis of sustainable investments in the Brazilian stock market: A study about the Corporate Sustainability Index (ISE). J. Bus. Ethics 2013, 117, 19-36.

26. Sudha, S. Risk-return and volatility analysis of sustainability index in India. Environ. Dev. Sustain. J. 2015, 17, 1329-1342. [CrossRef]

27. Van Stekelenburg, A.; Georgakopoulos, G.; Sotiropoulou, V.; Vasileiou, K.Z.; Vlachos, I. The relation between sustainability performance and stock market returns: An empirical analysis of the Dow Jones Sustainability Index Europe. Int. J. Econ. Financ. 2015, 7, 74-88. [CrossRef]

28. Robinson, M.; Kleffner, A.; Bertels, S. Signaling sustainability leadership: Empirical evidence of the value of DJSI membership. J. Bus. Ethics 2011, 101, 493-505. [CrossRef]

29. Joshi, S.; Pandey, V.; Ross, R.B. Asymmetry in stock market reactions to changes in membership of the Dow Jones Sustainability Index. J. Bus. Inq. 2017, 16, 12-35.

30. Hayward, L. Does the stock market value inclusion on a sustainability index? An event study using the Dow Jones Sustainability North America Index. Economics Department Honors Thesis, College of the Holy Cross, Worcester, MA, USA, 2018.

31. Orlitzky, M.; Schmidt, F.L.; Rynes, S.L. Corporate social and financial performance: A meta-analysis. Organ. Stud. 2003, 24, 403-441. [CrossRef]

32. Schnietz, K.E.; Epstein, M.J. Exploring the financial value of a reputation for corporate social responsibility during a crisis. Corp. Reput. Rev. 2005, 7, 327-345. [CrossRef]

33. Karpoff, J.M.; Lee, D.S.; Martin, G.S. The cost to firms of cooking the books. J. Financ. Quant. Anal. 2008, 43, 581-611. [CrossRef]

34. Hawn, O.; Chatterji, A.; Mitchell, W. How firm performance moderates the effect of changes in status on investor perceptions: Additions and deletions by the Dow Jones Sustainability Index. SSRN Electron. J. 2014. [CrossRef]

35. Citak, L.; Akel, V.; Ersoy, E. Investors' reactions to announcement of new constituents of BIST Sustainability Index: An analysis by the event study and mean-median tests. In Value Sharing for Sustainable and Inclusive Development; IFI Global: Hershey, PA, USA, 2018.

36. Fowler, S.J.; Hope, C. A critical review of sustainable business indices and their impact. J. Bus. Ethics 2007, 76, 243-252. [CrossRef]

37. Dorfleitner, G.; Utz, S.; Wimmer, M. Patience pays off-Corporate social responsibility and long-term stock returns. J. Sustain. Financ. Invest. 2018, 8, 132-157. [CrossRef]

38. Haan, M.; Dam, L.; Scholtens, B. The drivers of the relationship between corporate environmental performance and stock market returns. J. Sustain. Financ. Investig. 2012, 2, 338-375.

39. Shleifer, A.; Vishny, R.W. A survey of corporate governance. J. Financ. 1997, 52, 737-783. [CrossRef]

40. Tirole, J. The Theory of Corporate Finance; Princeton University Press: Princeton, NJ, USA, 2006. 
41. Boutin-Dufresne, F.; Savaria, P. Corporate social responsibility and financial risk. J. Investig. 2004, 13, 57-66. [CrossRef]

42. Lee, D.D.; Faff, R.W. Corporate sustainability performance and idiosyncratic risk: A global perspective. Financ. Rev. 2009, 44, 213-237. [CrossRef]

43. Hoepner, A.G.F. Portfolio diversification and environmental, social and governance criteria: Must responsible investments really be poorly diversified? SSRN Electron. J. 2010, 1599334, 1-16. [CrossRef]

44. Godfrey, P.C.; Merrill, C.B.; Hansen, J.M. The relationship between corporate social responsibility and shareholder value: An empirical test of the risk management hypothesis. Strateg. Manag. J. 2009, 30, 425-445. [CrossRef]

45. Kumar, N.C.A.; Smith, C.; Badis, L.; Wang, N.; Ambrosy, P.; Tavares, R. ESG factors and risk-adjusted performance: A new quantitative model. J. Sustain. Financ. Investig. 2016, 6, 292-300. [CrossRef]

46. Chapple, W.; Moon, J. Corporate social responsibility (CSR) in Asia: A seven country study of CSR web site reporting. Bus. Soc. 2005, 44, 415-441. [CrossRef]

47. Clark, G.L.; Hebb, T. Why should they care? The role of institutional investors in the market for corporate social responsibility. Environ. Plan. A 2005, 37, 2015-2031. [CrossRef]

48. Rakotomavo, M.T.J. Preferences of retail investors and institutions for corporate social performance. J. Sustain. Financ. Investig. 2011, 1, 93-102.

49. Dyck, A.; Lins, K.V.; Roth, L.; Wagner, H.F. Do institutional investors drive corporate social responsibility? International evidence. J. Financ. Econ. 2019, 131, 693-714. [CrossRef]

50. Epstein, M.J.; Schneitz, K.E. Measuring the cost of environmental and labor protests to globalization: An event study of the failed 1999 Seattle WTO Talks. Int. Trade J. 2002, 16, 129-160. [CrossRef]

51. Bouslah, K.; Kryzanowski, L.; M'Zali, B. Social performance and firm risk: Impact of the financial crisis. J. Bus. Ethics 2018, 149, 643-669. [CrossRef] [PubMed]

52. Cable, J.; Holland, K. Modelling normal returns in event studies: A model-selection approach and pilot study. Eur. J. Financ. 1999, 5, 331-341. [CrossRef]

53. Lameria, V.J.; Ness, W.L.; Quelhas, O.L.G.; Pereira, R.G. Sustainability, value, performance and risk in the Brazilian capital markets. Revista Brasileira de Gestao de Negocios 2013, 15, 76-90. [CrossRef]

54. Durand, R.; Paugam, L.; Stolowy, H. Do investors actually value sustainability indices? Replication, development and new evidence on CSR visibility. Strateg. Manag. J. 2019, 40, 1471-1490. [CrossRef] 